\title{
Dry olive leaf extract attenuates DNA damage induced by estradiol and diethylstilbestrol in human peripheral blood cells in vitro
}

\author{
Dijana Topalovića,*, Dragana Dekanski ${ }^{\mathrm{b}}$, Biljana Spremo-Potparevića ${ }^{\mathrm{a}}$, Andrea Pirkovića ${ }^{\mathrm{a}}$, \\ Sunčica Borozan ${ }^{\mathrm{c}}$, Vladan Bajićc ${ }^{\mathrm{d}}$, Danilo Stojanoviće ${ }^{\mathrm{e}}$, Francesca Giampieri ${ }^{\mathrm{f}}$, \\ Massimiliano Gasparrini ${ }^{\mathrm{f}}$, Lada Živković ${ }^{\mathrm{a}}$ \\ ${ }^{a}$ Department of Pathobiology, Faculty of Pharmacy, University of Belgrade, Vojvode Stepe 450, 11000 Belgrade, Serbia \\ ${ }^{\mathrm{b}}$ Biomedical Research, R\&D Institute, Galenika a.d., Pasterova 2, 11000 Belgrade, Serbia \\ ${ }^{\mathrm{c}}$ Department of Chemistry, Faculty of Veterinary Medicine, University of Belgrade, Bulevar Oslobodjenja 18, 11000 Belgrade, Serbia \\ d The Laboratory for Radiobiology and Molecular Genetics, Institute for Nuclear Research "Vinča”, University of Belgrade, Mike Petrovića Alasa 12-14, 11000 Belgrade, \\ Serbia \\ ${ }^{\mathrm{e}}$ Department of Botany, Faculty of Pharmacy, University of Belgrade, Vojvode Stepe 450, 11000 Belgrade, Serbia \\ ${ }^{\mathrm{f}}$ Department of Odontostomatologic and Specialized Clinical Science, Faculty of Medicine, Polytechnic University of Marche, Ancona, Italy
}

\section{A R T I C L E I N F O}

\section{Keywords:}

DOLE

$17 \beta$-estradiol

DES

Antigenotoxicity

Comet assay

\begin{abstract}
A B S T R A C T
Phenolic groups of steroidal or nonsteroidal estrogens can redox cycle, leading to oxidative stress, where creation of reactive oxygen species are recognized as the main mechanism of their DNA damage properties. Dry olive (Olea europaea L.) leaf extract is known to contain bioactive and antioxidative components and to have an ability to modulate the effects of various oxidants in cells. The main goal of this study was to investigate antigenotoxic potential of a standardized dry olive leaf extract on DNA damage induced by $17 \beta$-estradiol and diethylstilbestrol in human whole blood cells in vitro, using comet assay. Our results indicated that both hormones showed a genotoxic effect at a concentration of $100 \mu \mathrm{M}(\mathrm{P}<0.05, \mathrm{n}=6)$. Dry olive leaf extract was efficient in reducing number of cells with estrogen-induced DNA damage at tested concentrations $(0.125,0.5$ and $1 \mathrm{mg} / \mathrm{mL})(\mathrm{P}<0.05, \mathrm{n}=6$ ) and under two experimental protocols, pre-treatment and post-treatment, exhibiting antigenotoxic properties. Analysis of antioxidant properties of the extract revealed moderate ABTS radical scavenging properties and reducing power. Overall, our results suggested that the protective potential of dry olive leaf extract could arise from the synergistic effect of its scavenging activity and enhancement of the cells' antioxidant capacity.
\end{abstract}

\section{Introduction}

Naturally occurring estrogens (estrone (E1), estradiol (E2) and estriol (E3)) are involved in the control of the development and maintenance of female sex organs and secondary sex characteristics, and they have an influence on the skin, bone, cardiovascular system and immunity. Estrogens also have some direct effects on metabolic processes, including those affecting lipids, carbohydrates, and proteins [1]. Estrogen-like compounds are used therapeutically, the application of natural estrogens and synthetically produced related substances are broad and cover many conditions. However, long-term exposure to higher levels of estrogens and estrogen-like compounds are associated with the range of adverse effects including development of different types of cancer [2,3].

There is evidence of estrogen-mediated genotoxicity in various in vitro and in vivo systems [4,5]. Previous studies have demonstrated that 17ß-estradiol induced sister chromatid exchanges [6], breaks and aneuploidies [7] as well as ROS generated DNA damage confirmed by comet assay in human lymphocytes and sperm [8]. Diethylstilbestrol (DES), a synthetic nonsteroidal analogue of estradiol, displays

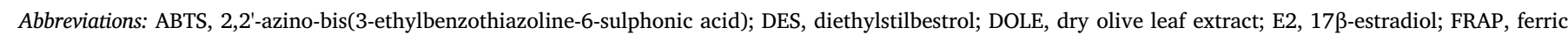
antioxidant power; ROS, reactive oxygen species

* Corresponding author.

E-mail addresses: dijana.topalovic@pharmacy.bg.ac.rs (D. Topalović), ddekan@sezampro.rs (D. Dekanski),

biljana.potparevic@pharmacy.bg.ac.rs (B. Spremo-Potparević), andrea@pharmacy.bg.ac.rs (A. Pirković), sborozan@vet.bg.ac.rs (S. Borozan),

vladanbajic@yahoo.com (V. Bajić), danilo.stojanovic@pharmacy.bg.ac.rs (D. Stojanović), f.giampieri@univpm.it (F. Giampieri),

m.gasparrini@univpm.it (M. Gasparrini), lada.zivkovic@pharmacy.bg.ac.rs (L. Živković). 
teratogenic effects, induced sister chromatid exchanges [9] and also exerted comet assay confirmed DNA damaging activity in human lymphocytes and sperm [3,8]. It is well known that estrogen-like compounds mediate DNA damage by the generation of reactive oxygen species (ROS), implying that their effects can be modulated by antioxidants such as catalase, superoxide dismutase, and vitamin C $[8,9]$.

Bearing in mind that oxidatively damaged DNA plays a significant role in estrogen-induced genotoxicity, decreasing oxidative stress seems to be one of the best preventive and therapeutic strategies. Olive leaf extract, from the Mediterranean olive tree (Olea europaea L.), is one of the polyphenol-rich plant extracts containing polyphenols at much higher concentration then extra virgin olive oil [10]. The main constituent of a standardized dry olive leaf extract (DOLE) is secoiridoid oleuropein, but it also contains triterpenes, flavonoids, caffeic acid and tannins [11]. Numerous in vitro and in vivo studies have confirmed beneficial effects of DOLE and its individual constituents, including the antiatherogenic, antiinflammatory, anticancerogenic, and high antioxidant activity [12-14]. DOLE pronounced antioxidant properties in in vitro systems were ascribed to the phenolic metabolites, which also exert a significant antioxidant action in vivo even after extracts digestion [15]. In fact, it has been found that extract has highest antioxidant/ radical-scavenging activity than vitamins $\mathrm{C}$ and $\mathrm{E}$ [16]. The protective effect of DOLE on hydrogen peroxide- $\left(\mathrm{H}_{2} \mathrm{O}_{2}\right)$ induced oxidatively damaged DNA, phorbol myristate acetate- and permethrin-induced genotoxicity is described previously $[17,18]$. Furthermore, DOLE capacity to attenuate adrenaline- and thyroxine-induced DNA damage in human peripheral blood leukocytes was recently demonstrated $[19,20]$.

The main goal of this study was to investigate the antigenotoxic potential of a standardized dry olive leaf extract on DNA damage induced by two estrogenic compounds, 17ß-estradiol and diethylstilbestrol, in human peripheral blood cells by comet assay. Also, the objective was to assess antioxidant potential of DOLE using reducing power test (FRAP assay) and scavenging assay (ABTS assay).

\section{Material and methods}

\subsection{Subjects}

Whole blood samples from six healthy volunteers ( 5 female and 1 male) aged between 18 and 40 years were collected in heparinized containers using a fingerprick and used while fresh. Volunteers were non-smokers, did not consume alcohol or receive any therapy, medications or take dietary supplements. The protocol and the informed consent forms were approved by the Ethics Committee of Faculty of Pharmacy, University of Belgrade, Serbia (permit No. 1103/2).

\subsection{Study design}

For our study design, 17ß-estradiol (CAS No. 50-28-2, SigmaAldrich Chemie, St. Louis, MO) and diethylstilbestrol (CAS No. 56-53-1, Sigma-Aldrich Chemie, St. Louis, MO) were used. Dry olive leaf extract EFLA $^{\oplus} 943$ (Frutarom Switzerland Ltd., Wadenswil, Switzerland) was originally manufactured applying an ethanol extraction procedure (80\%), standardized to $16-24 \%$ of oleuropein. Manufacturer's certificate of analysis confirmed stability and microbiological purity, as well as partial content of this EFLA ${ }^{\circledR} 943$ batch - oleuropein (17\%), polyphenols (40.5\%), acaciae gummi Ph. Eur. (carrier, 15\%) and silica colloidalis anydr. Ph. Eur. (max $2 \%$ ). Previous phytochemical analysis, using high performance liquid chromatography (HPLC), showed more detailed content - apigenine-7-O-glucoside $(0.07 \%)$, quercetin $(0.04 \%)$ and caffeic acid $(0.02 \%)$ [21].

To determine the proper concentrations of E2 and DES in the comet assay, both hormones were pre-examined at several concentrations ranging from $0.07 \mu \mathrm{M}$ to $210 \mu \mathrm{M}$. Concentrations of $\mathrm{E} 2$ are comparable to the blood level of treated women and ranged from physiological to 30-fold higher doses than maximal therapeutic doses [6]. Since DES is nonsteroidal analogue of estradiol, it was tested in the same concentrations as E2. Tested concentrations of E2 and DES corresponded to the ones used in previous studies of both estrogens $[3,6]$. For genotoxicity testing, all cell preparations were incubated with hormones at $37^{\circ} \mathrm{C}$ for $30 \mathrm{~min}$, together with negative controls treated only with phosphate buffered saline (PBS, Fisher Scientific, Pittsburgh, PA), as well as with positive controls, treated previously with $\mathrm{H}_{2} \mathrm{O}_{2}(50 \mu \mathrm{M}$, CAS No. 7722-84-1, ZORKA Pharma, Šabac, Serbia) for $20 \mathrm{~min}$ at $4^{\circ} \mathrm{C}$. The concentrations of $100 \mu \mathrm{M}$ E2 and DES were chosen for further testing in our study, since they produced a significant level of DNA damage in treated cells while retaining good cell viability. The viability of cells was checked with trypan blue exclusion method, and the cell viability was above $90 \%$.

For the evaluation of its antigenotoxic potential, DOLE powder was diluted in PBS to three final concentrations: $0.125,0.5$ and $1 \mathrm{mg} / \mathrm{mL}$. These were determined based on the range of concentrations documented to be safe and effective in previous in vitro experiments [18-20]. To evaluate positive effect of DOLE, we performed two experimental designs: pre-treatment, for DOLE ability to prevent estrogens-induced DNA damage and post-treatment, for DOLE ability to intervene after the treatment with hormones. In the first series (pretreatment protocol), three final concentrations of the extract were applied to the cells, incubated at $37^{\circ} \mathrm{C}$ for $30 \mathrm{~min}$, washed with PBS and then treated with $\mathrm{E} 2$ or DES for $30 \mathrm{~min}$ on $37^{\circ} \mathrm{C}$. In the second series (post-treatment protocol), cell preparations were firstly exposed to hormones separately, washed with PBS and then post-treated with same concentrations of DOLE. In both treatments, quercetin $(500 \mu \mathrm{M})$ was used as a positive control, treated as described above. This concentration was chosen according to literature data [8] and also it was the most effective concentration in our previous studies [22]. For negative control in pre-treatment, samples were incubated for $30 \mathrm{~min}$ on $37^{\circ} \mathrm{C}$, firstly with PBS and afterwards exposed to E2 or DES, while in posttreatment, cells were also incubated for $30 \mathrm{~min}$ on $37^{\circ} \mathrm{C}$, firstly exposed to E2 or DES and afterwards incubated with PBS.

\subsection{The single cell gel electrophoresis assay (comet assay)}

The comet assay was performed as described by Singh et al. [23]. All experiments were repeated six times, carried out in duplicate. 100 randomly selected nucleoids per slide and two slides per blood sample were manually scored and the results of six independent experiments were averaged. The comets were analyzed on Olympus BX 50 microscope (Olympus Optical Co., GmbH, Hamburg, Germany) at magnification of 100X, equipped with a mercury lamp $\mathrm{HBO}(50 \mathrm{~W}$, 516-560 nm, Zeiss). DNA damage was evaluated according to Anderson et al. [24]. Comets were visually scored and classified into five categories corresponding to the extent of DNA migration: (A) no damage, < 5\%; (B) low level damage, 5-20\%; (C) medium level damage, 20-40\%; (D) high level damage, 40-95\%; (E) total damage, > 95\%. The presented DNA damage was characterized as the total DNA migration over $5 \%$ (B + C + D + E comet classes) for $n=6$.

\subsection{Spectrophotometric evaluation of antioxidant capacity of dry olive leaf extract}

\subsubsection{Ferric antioxidant power (FRAP) assay}

The reducing power of DOLE at concentrations range $0.0175-17.5 \mathrm{mg} / \mathrm{mL}$ was determined according to Benzie and Strain [25], with minor modification. The fresh FRAP solution was prepared by adding $2.5 \mathrm{~mL}$ of a $10 \mathrm{mM}$ TPTZ (2,4,6-tripyridyl-s-triazine) solution in $40 \mathrm{mM} \mathrm{HCl}, 2.5 \mathrm{~mL}$ of $20 \mathrm{mM} \mathrm{FeCl}_{3}$, and $25 \mathrm{~mL}$ of $0.3 \mathrm{M}$ acetate buffer (pH of 3.6). $100 \mu \mathrm{l}$ of a blank sample, iron sulphate standard and $10 x$ dilution of the extract in milliQ water were mixed with $900 \mu \mathrm{L}$ of FRAP reagent, and the absorbance was measured spectrophotometrically at $593 \mathrm{~nm}$ against a blank sample. Trolox was used for the calibration curve, and the results were expressed as $\mu$ mol of Trolox equivalent (TE) per $1 \mathrm{~g}$ of the extract ( $\mu \mathrm{molFeEk} / \mathrm{g} \mathrm{FV}$ ). 


\subsubsection{2,2'-azino-bis(3-ethylbenzothiazoline-6-sulphonic acid) (ABTS) assay}

The radical scavenging capacity of DOLE was determined according to Re et al. [26], with slight modifications. The activation of the ABTS $+\cdot$ was achieved by adding $7 \mathrm{mM}$ ABTS solution with $2.45 \mathrm{mM}$ potassium persulfate solution. One $\mathrm{mL}$ of ABTS + solution (diluted 1:50 with PBS on $\mathrm{pH}$ 7.4) was added to $10 \mu \mathrm{L}$ of a) ethanol for standard curve control, b) ethanol:water (80:20) for extract control and c) DOLE, and the mixtures were kept in the dark for 1-3 min. The absorbance of the sample and blank (milliQ water) was measured at $734 \mathrm{~nm}$. The antioxidant capacity of the investigated extract was calculated by following formula:

$\%$ inhibition734 $\mathrm{nm}=[($ control Abs734 $\mathrm{nm}-$ sample Abs734 nm $) /$ control Abs734 nm] $\times 100$.

\subsection{Statistical analysis}

The extent of DNA damage was expressed as the mean value ( \pm standard error of mean (SEM) of the number of cells with migrated DNA (classes B, C, D and E). Values for the antioxidant capacity of the extract were expressed as means \pm standard deviation (SD). In all experiments, the data were analyzed for statistical significance using analysis of variance (one-way ANOVA) with Tukey's post-hoc test for comparisons of different treatments vs. the respective control. All data were analyzed with the GraphPad Prism 5.0 software. A difference at $\mathrm{P}<0.05$ was considered statistically significant.

\section{Results}

\subsection{Evaluation of genotoxic potential of estrogens and antigenotoxic potential of DOLE}

The results of this study showed that E2 and DES were able to cause DNA damage in approximately $30 \%$ of treated cells (Fig. 1). Fig. 1 also represents the genotoxic effect of oxidants expressed with two DNA damage distribution variables: the mean value for low and medium damage (B + C comet category) and the mean value for high and total DNA damage ( $D+E$ comet category) within the number of cells with migrated DNA. Although total number of comets is approximately the same, degree of DNA damage presented with two variables indicates that there are higher levels of DNA migration in cells treated with

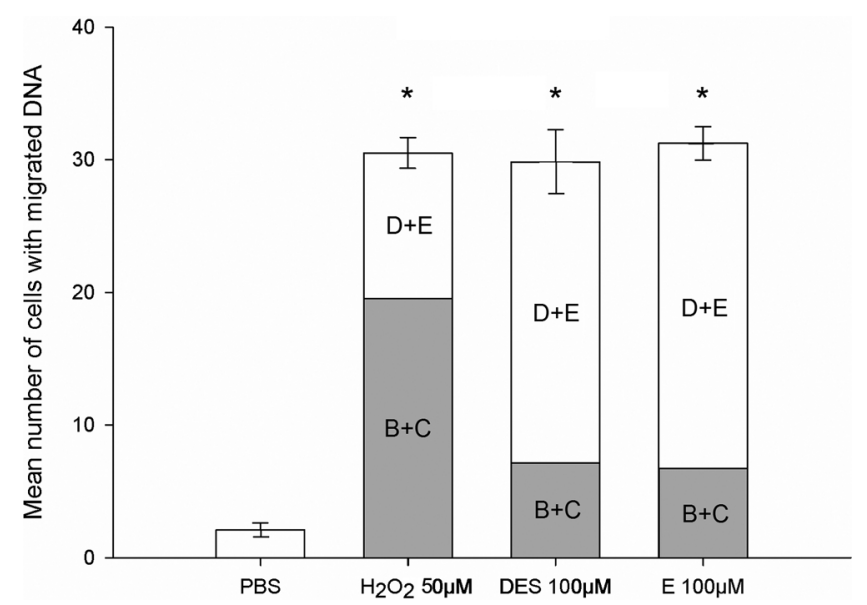

Fig. 1. DNA damage in human peripheral blood cells exposed to $\mathrm{H}_{2} \mathrm{O}_{2}$ as positive control, diethylstilbestrol (DES) and estradiol (E2) separately, compared to negative control treated with PBS. Values are expressed as mean number of comets and two distribution variables ( $+C$ and $D+E$ category) ( \pm SEM) per 100 nucleoids for $\mathrm{n}=6$. * vs. PBS, $\mathrm{P}<0.05$. hormones (D + E comet category) than the ones treated with $\mathrm{H}_{2} \mathrm{O}_{2}$ (B + C comet category).

The protective effect of DOLE in human peripheral blood cells was evaluated for its ability to prevent E2- and DES-induced DNA damage. While an increase in the number of cells with DNA damage was detected in the treatment either with estradiol or DES, the number of cells with DNA damage decreased in treatment with different concentrations of DOLE in both pre-treatment (Fig. 2) and post-treatment (Fig. 3). It was evident that all three concentrations of DOLE significantly reduced the number of cells with damaged DNA under both experimental protocols, but without concentration dependence.

Regarding the antigenotoxic effect of different concentrations of DOLE, it appeared that the positive effect on DNA damage induced by estrogens was quite uniform in pre-treatment and post-treatment. The effects of treatment with positive control quercetin are visible on Figs. 2 and 3. Our results show that quercetin significantly decreased number of cells with DNA damage exposed to E2 and DES in pre-treatment (10.33\% for E2 and $4.67 \%$ for DES) and post-treatment (15.17\% for E2 and $17.33 \%$ for DES), with its effect being more pronounced in the pretreatment. Also, quercetin was significantly more effective in pretreatment than DOLE (Fig. 2).

\subsection{Evaluation of antioxidant capacity of dry olive leaf extract}

\subsubsection{Determination of the reducing power of DOLE}

The reducing power of tested concentrations of DOLE is presented in Fig. 4. Based on the obtained results, it is obvious that significant reducing power of the extract is detected at the concentration of $1.75 \mathrm{mg} /$ $\mathrm{mL}$, while the best reducing power (highest FRAP value) was shown at the highest concentration $(17.5 \mathrm{mg} / \mathrm{mL})$.

\subsubsection{Determination of ABTS radical scavenging activity of DOLE}

Antioxidative ability of different concentrations of DOLE, expressed as percentage of ABTS radicals inhibition, is presented in Fig. 5. Our results showed a dose-dependent ability of DOLE to perform ABTS inhibition activity. The complete inhibition was achieved at a concentration of around $17.5 \mathrm{mg} / \mathrm{mL}$, while the $50 \%$ inhibition was obtained with a concentration of $1.75 \mathrm{mg} / \mathrm{mL}$, indicating a moderate antioxidant activity of the extract.

\section{Discussion}

Primary estrogens undergo aromatic hydroxylation, forming catechol estrogens. Catecholestrogens and DES are activated to semiquinones and quinones, which enables their involvement in redox cycling which may create conditions of oxidative stress [4]. Semiquinones and quinones may damage DNA directly or by forming oxygen radicals [5,7]. Various types of free radical-generated DNA lesions have been reported to be induced by steroidal or nonsteroidal estrogen metabolites [2,5]. Our current data displayed that $17 \beta$-estradiol and diethylstilbestrol at concentration of $100 \mu \mathrm{M}$ were able to cause DNA damage in human peripheral blood cells. Namely, in this study we showed that E2 and DES induce DNA damage in approximately $30 \%$ of treated cells, of which $70 \%$ were highly and totally damaged (D + E categories). $\mathrm{H}_{2} \mathrm{O}_{2}$, the positive control in genotoxicity testing, also induced DNA damage in around $30 \%$ of treated cells, where $70 \%$ of its induced DNA damage was of lower extent (B + C categories). Since concentrations used in this study exceed therapeutic doses, this can be surmised as reason for observed higher levels of DNA migration induced by estrogens. Our results also show that antioxidant flavonoid quercetin, at concentration of $500 \mu \mathrm{M}$ displayed significant ability to attenuate estrogen-induced DNA damage, which is in concordance with previous findings [8]. It is already postulated that estrogens most likely operate by inducing oxidatively damaged DNA, with generation of ROS as the main mechanism of their action $[7,8]$, so our findings lead to the presumption that E2 and DES exhibited genotoxicity mainly through production of ROS. 


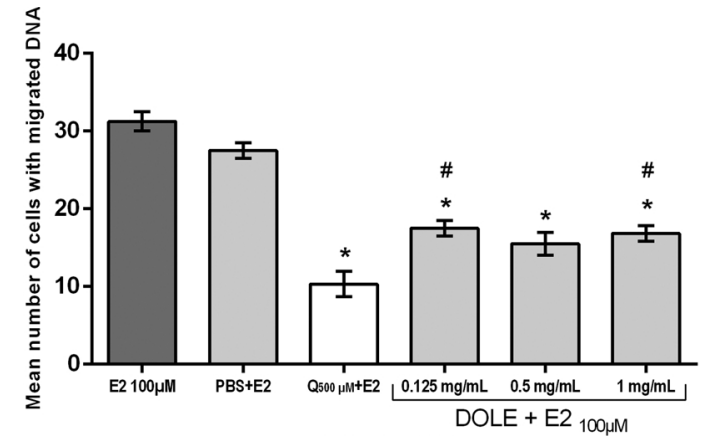

a) pre-treatment

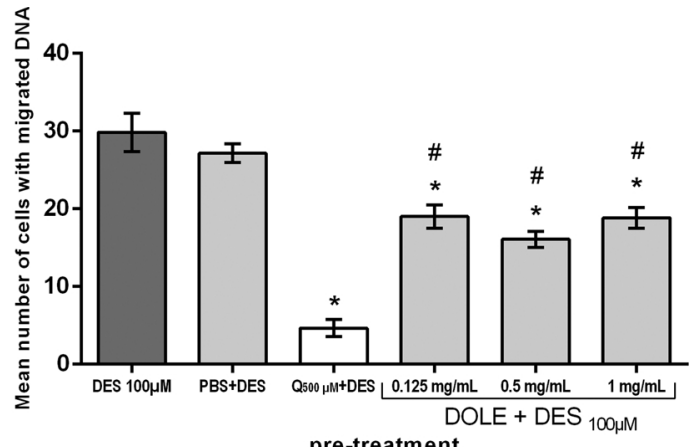

b)

pre-treatment

Fig. 2. Pre-treatment protocol - number of cells with migrated DNA, first pretreated with 3 concentration of DOLE and subsequently exposed to (2a) estradiol (E2) and (2b) diethylstilbestrol (DES). Negative controls were pretreated with PBS and exposed to hormones, while positive controls were pretreated with quercetin and exposed to hormones. Values are expressed as mean number of comets ( $+\mathrm{C}+\mathrm{D}+\mathrm{E}$ category) ( \pm SEM) per 100 nucleoids for $\mathrm{n}=6$. * vs. oxidant, $\mathrm{P}<0.05$, \# vs positive control, $\mathrm{P}<0.05$.
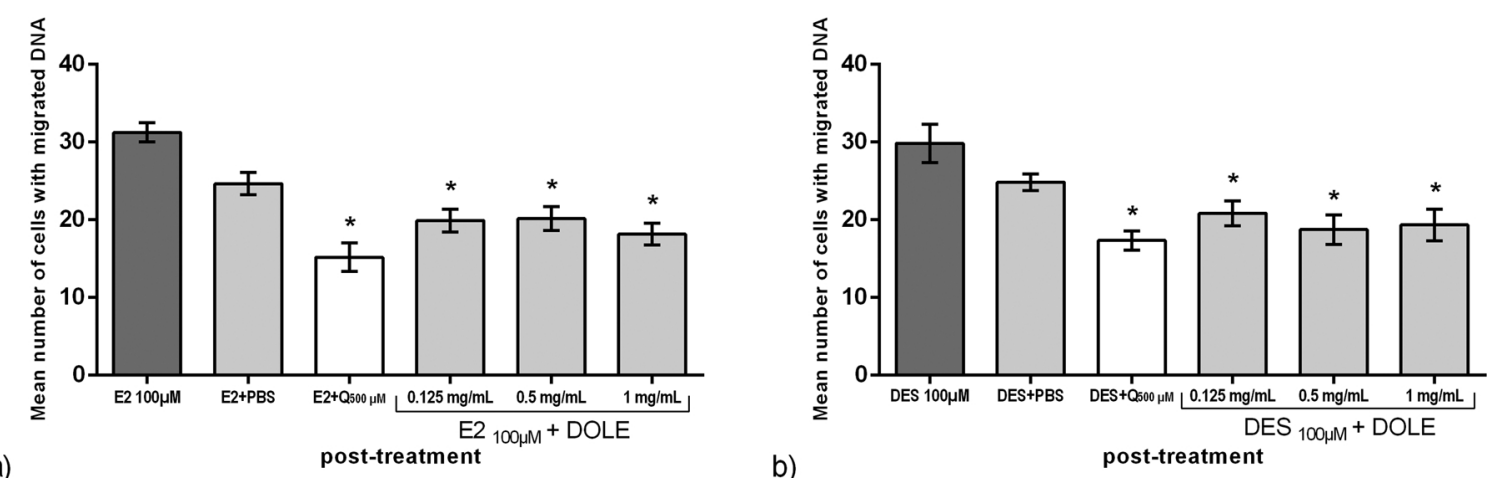

b)

post-treatment

Fig. 3. Post-treatment protocol - number of cells with migrated DNA, first treated with (3a) estradiol (E2) and (3b) diethylstilbestrol (DES), and subsequently incubated with 3 concentrations of DOLE. Negative controls were pretreated with hormones and then exposed to PBS, while positive controls were pretreated with hormones and then exposed to quercetin. Values are expressed as mean number of comets (B + C +D + E category) ( \pm SEM) per 100 nucleoids for $n=6$. * vs. oxidant, $\mathrm{P}<0.05$.

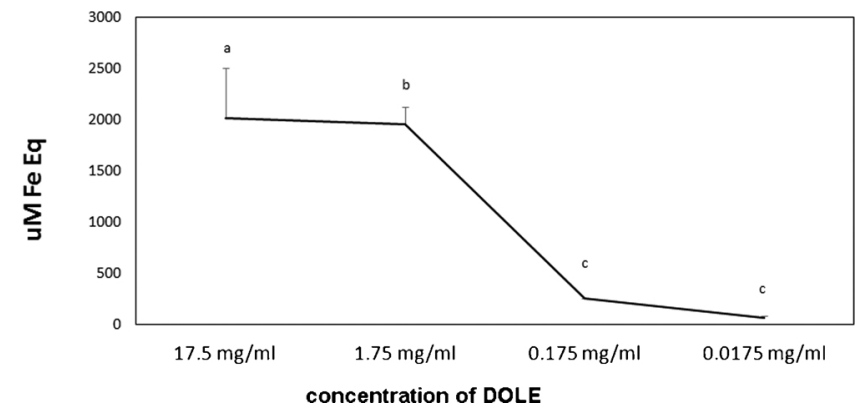

Fig. 4. The reducing power of different concentrations of DOLE in the FRAP assay. Values are expressed as mean $\pm \mathrm{SD}$. ${ }^{\mathrm{a}, \mathrm{b}, \mathrm{c}}$ vs. control ${ }^{\mathrm{a}} \mathrm{p}<0.001{ }^{\mathrm{b}}$ $\mathrm{p}<0.01,{ }^{\mathrm{c}} \mathrm{p}<0.05$.

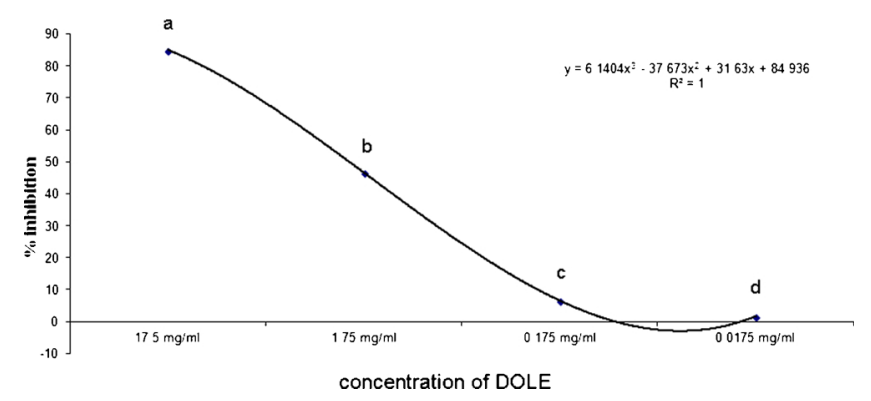

Fig. 5. ABTS radical scavenging ability of DOLE. Values are expressed as mean \pm SD. ${ }^{\mathrm{a}, \mathrm{b}, \mathrm{c}}$ vs. control ${ }^{\mathrm{a}} \mathrm{p}<0.0001,{ }^{\mathrm{b}} \mathrm{p}<0.001,{ }^{\mathrm{c}} \mathrm{p}<0.01,{ }^{\mathrm{d}}$ $\mathrm{p}<0.05$.
DOLE is proven to be able to decrease DNA damage in cells induced by oxidizing agents $[18,20]$. To the best of our knowledge, this is the first study to examine the ability of DOLE to inhibit DNA damage induced by estrogens. Results of this study show that all concentrations of DOLE that were used, displayed DNA protective effect against genotoxicity of estrogens under both experimental conditions, pre-treatment and post-treatment. As stated earlier, $40.5 \%$ constituents of DOLE are polyphenols, predominantly flavonoids. Previous studies have shown that there is a decrease of the level of intracellular ROS induced by $\mathrm{H}_{2} \mathrm{O}_{2}$ with the increase of polyphenol content in lymphocytes treated with several plant extracts [27]. Flavonoids are probably operating through antioxidant properties as predominant feature of their radicalscavenging capacity [8]. However, it cannot be excluded that flavonoids also act through stimulation of DNA repair and other mechanisms for antigenotoxicity $[7,8]$.

Different experimental protocols used in this study enabled the assessment of the mechanisms involved in DOLE antigenotoxic effect. Its efficiency in pre-treatment protocol can partially be explained by previously reported ability of DOLE to increase the antioxidant capacity of cells, mostly by stimulating and maintaining the activity of antioxidant enzymes during oxidative stress [28]. The second mechanism of DOLE action may be expressed directly, by acting as free radical scavenger. Scavenging capacity of DOLE in ABTS assay showed that its efficiency is dependent on the concentration, and that the significant neutralization of free radical activity is achieved at concentrations higher than $1.75 \mathrm{mg} / \mathrm{mL}$. This is in concordance with the results of the reducing power of DOLE obtained in the FRAP assay. Our previous findings of DOLE ability to reduce DPPH radicals are consistent with these findings [12], and confirm the antioxidant capacity of the extract in vitro. Other 
in vitro studies have shown that DOLE polyphenol components quercetin and oleuropein alone, also protect DNA against oxidative damage mainly by scavenging several types of free radicals $[8,29]$. Our finding that there was a significant difference between the results of quercetin and DOLE in pre-treatment implies that the scavenging effect of quercetin might be overshadowed in the extract mixture by properties of the other constituents. Although antioxidant activity of DOLE can mainly be assigned to its high content of polyphenols, it is known that a synergy between the main components is responsible for its radical scavenging capacity $[16,21]$. Also, concentration and bioavailability of DOLE and its free radicals reduction potential $[8,30]$ could also be the contributing factors to the overall results.

The antigenotoxic effect of DOLE in post-treatment can probably be attributed to the simultaneous activation of the cell antioxidant capacity, scavenging of free radicals and stimulation of cell DNA repair $[19,22]$. Since our data showed that the positive effect of DOLE on estrogen-induced DNA damage was quite uniform in pre-treatment and post-treatment, we can assume that DOLE activation of DNA repair did not participate in its overall protective effect. Consequently, the effect of DOLE in post-treatment could be assigned mostly to the synergism of cells antioxidant capacity enhancement and its scavenging activity.

Based on our findings, DOLE can prevent estrogen induced primary DNA damage. The obtained results show a property of E2 and DES as mediators of DNA damage, which can be reduced by nutrient antioxidants. Since oxidatively damaged DNA plays a significant role in mutagenesis, aging, cancer and other diseases, eating food rich in antioxidants or taking supplements, such as polyphenol-rich DOLE, seems to be good strategy to decrease oxidative stress. DOLE could be considered as possible candidate for supplementation in women on estrogen therapy, but further in vivo investigations as well as clinical trials of its antigenotoxic potential would be beneficial.

\section{Conclusions}

$17 \beta$-estradiol and diethylstilbestrol express a genotoxic effect in treatments of peripheral blood cells in vitro, with generation of ROS being probably the main mechanism of its action. DOLE is efficient in reducing the number of cells with primary DNA damage induced by estrogens, exhibiting antigenotoxic properties. The protective potential of DOLE could arise from the synergistic effect of its scavenging activity and enhancement of the cells' antioxidant capacity.

\section{Conflict of interest}

The authors declare no conflict of interest.

\section{Acknowledgments}

This research was supported by the Ministry of Education, Science and Technological Development of the Republic of Serbia [Grant OI 173034] and the hCOMET COST [Action No 15132].

\section{References}

[1] S.C. Sweetman, Sex hormones and their modulators, in: S.C. Sweetman (Ed.), Martindale-The Complete Drug Reference, 36th edn., The Pharmaceutical Press, London, 2009, pp. 2058-2137.

[2] E. Yagi, J.C. Barrett, T. Tsutsui, The ability of four catechol estrogens of 17betaestradiol and estrone to induce DNA adducts in Syrian hamster embryo fibroblasts, Carcinogenesis 22 (2009) 1505-1510.

[3] E. Cemeli, A. Anderson, Mechanistic investigation of ROS-Induced DNA damage by oestrogenic compounds in lymphocytes and sperm using the comet assay, Int. J. Mol. Sci. 12 (2011) 2783-2796, https://doi.org/10.3390/ijms12052783.

[4] E. Cavalieri, K. Frenkel, J.G. Liehr, E. Rogan, D. Roy, Estrogens as endogenous genotoxic agents-DNA adducts and mutations, J. Natl. Cancer Inst. Monogr. 27 (2000) 75-93, https://doi.org/10.1093/oxfordjournals jncimonographs.a024247.

[5] N. Rajapakse, M. Butterworth, A. Kortenkamp, Detection of DNA strand breaks and oxidized DNA bases at the single-cell level resulting from exposure to estradiol and hydroxylated metabolites, Environ. Mol. Mutagen. 45 (2005) 397-404, https://doi. org/10.1002/em.20104

[6] N. Djelić, B. Spremo-Potparević, B. Marković, L. Živković, D. Djelić, Cell cycle kinetics and cytogenetic changes in human lymphocytes exposed to oestradiol in vitro, Acta Vet. Beograd 56 (2006) 37-48.

[7] D. Anderson, T.E. Schmid, A. Baumgartner, E. Cemeli-Carratala, M.H. Brinkworth, J.M. Wood, Oestrogenic compounds and oxidative stress (in human sperm and lymphocytes in the Comet assay), Mutat. Res. 544 (2003) 173-178, https://doi.org/ 10.1016/j.mrrev.2003.06.016.

[8] E. Cemeli, T.E. Schmid, D. Anderson, Modulation by flavonoids of DNA damage induced by estrogen-like compounds, Environ. Mol. Mutagen. 44 (2004) 420-426, https://doi.org/10.1002/em.20071.

[9] G.G.H.A. Shadab, M.E. Ahmad, M.A. Azfer, Anticlastogenic action of vitamin C against genotoxicity of estrogenic drug diethylstilbestrol (DES) in the human lymphocyte chromosomes, J. Environ. Biol. 27 (2006) 85-88.

[10] S. Silva, L. Gomes, F. Leitao, A.V. Coelho, L.V. Boas, Phenolic compounds and antioxidant activity of Olea europaea L. Fruits and leaves, Food Sci. Technol. Int. 12 (2006) 385-395, https://doi.org/10.1177/1082013206070166.

[11] D. Dekanski, S. Janićijević-Hudomal, V. Tadić, G. Marković, I. Arsić, D. Mitrović, Phytochemical analysis and gastroprotective activity of an olive leaf extract, J. Serb. Chem. Soc. 74 (2009) 367-377, https://doi.org/10.2298/JSC0904367D.

[12] A. Čabarkapa, D. Dekanski, L. Živković, M. Milanović-Čabarkapa, V. Bajić, D. Topalović, F. Giampieri, M. Gasparrini, M. Battino, B. Spremo-Potparević, Unexpected effect of dry olive leaf extract on the level of DNA damage in lymphocytes of lead intoxicated workers, before and after CaNa2EDTA chelation therapy, Food Chem. Toxicol. 106 (2017) 616-623, https://doi.org/10.1016/j.fct. 2016.12.023.

[13] M.M. Özcan, B. Matthäus, A review: benefit and bioactive properties of olive (Olea europaea L.) leaves, Eur. Food Res. Technol. 243 (2017) 89-99, https://doi.org/10 1007/s00217-016-2726-9.

[14] R. Fares, S. Bazzi, S.E. Baydoun, R.M. Abdel-Massih, The antioxidant and antiproliferative activity of the lebanese Olea europaea extract, Plant Foods Hum. Nutr. 66 (2011) 58-63, https://doi.org/10.1007/s11130-011-0213-9.

[15] D. Martín-Vertedor, M. Garrido, J.A. Pariente, J. Espino, J. Delgado-Adamez, Bioavailability of bioactive molecules from olive leaf extracts and its functional value, Phytoter. Res. 30 (2016) 1172-1179, https://doi.org/10.1002/ptr.5625.

[16] O. Benavente-Garcia, J. Castillo, J. Lorente, A. Ortuno, J.A. Del Rio, Antioxidant activity of phenolics extracted from Olea europaea L. Leaves, Food Chem. 68 (2000) 457-462, https://doi.org/10.1016/S0308-8146(99)00221-6.

[17] J. Anter, Z. Fernandez-Bedmar, M. Villatoro-Pulido, S. Demyda-Peyras, M. MorenoMillan, A. Alonso-Moraga, A. Muñoz-Serrano, M.D. Luque de Castro, A pilot study on the DNA-protective, cytotoxic, and apoptosis-inducing properties of olive-leaf extracts, Mutat. Res. 723 (2011) 65-170, https://doi.org/10.1016/j.mrgentox. 2011.05.005

[18] H. Turkez, B. Togar, Olive (Olea europaea L.) leaf extract counteracts genotoxicity and oxidative stress of permethrin in human lymphocytes, J. Toxicol. Sci. 36 (2011) 531-537, https://doi.org/10.2131/jts.36.531.

[19] A. Čabarkapa, L. Živković, D. Žukovec, N. Djelić, V. Bajić, D. Dekanski, B. SpremoPotparević, Protective effect of dry olive leaf extract in adrenaline induced DNA damage evaluated using in vitro comet assay with human peripheral leukocytes, Toxicol. In Vitro 28 (2014) 451-456, https://doi.org/10.1016/j.tiv.2013.12.014.

[20] D. Žukovec Topalović, L. Živković, A. Čabarkapa, N. Djelić, V. Bajić, D. Dekanski, B. Spremo-Potparević, Dry olive leaf extract counteracts L-Thyroxine-Induced genotoxicity in human peripheral blood leukocytes in vitro, Oxid. Med. Cell. Longev. 2015 (2015) 1-8, https://doi.org/10.1155/2015/762192 Article ID 762192 .

[21] D. Dekanski, V. Selaković, V. Piperski, ž. Radulović, A. Korenić, L. Radenović, Protective effect of olive leaf extract on hippocampal injury induced by transient global cerebral ischemia and reperfusion in Mongolian gerbils, Phytomedicine 18 (2011) 1137-1143, https://doi.org/10.1016/j.phymed.2011.05.010.

[22] L. Živković, S. Borozan, A. Čabarkapa, D. Topalović, U. Ciptasari, V. Bajić, B. Spremo-Potparević, Antigenotoxic properties of agaricus blazei against hydrogen peroxide in human peripheral blood cells, Oxid. Med. Cell. Longev. 2017 (2017) 9, https://doi.org/10.1155/2017/8759764 Article ID 8759764.

[23] N.P. Singh, M.T. McCoy, R.R. Tice, E.L. Schneider, A simple technique for quantitation of low levels of DNA damage in individual cells, Exp. Cell Res. 175 (1988) 184-191, https://doi.org/10.1016/0014-4827(88)90265-0.

[24] D. Anderson, T.W. Yu, B.J. Phillips, P. Schmezer, The effect of various antioxidants and other modifying agents on oxygen-radical-generated DNA damage in human lymphocytes in the comet assay, Mutat. Res. 307 (1994) 261-271, https://doi.org/ 10.1016/0027-5107(94)90300-X.

[25] I.F. Benzie, J.J. Strain, The ferric reducing ability of plasma (FRAP) as a measure of "antioxidant power": the FRAP assay, Anal. Biochem. 239 (1996) 70-76.

[26] R. Re, N. Pellegrini, A. Proteggente, A. Pannala, M. Yang, C. Rice-Evans, Antioxidant activity applying an improved ABTS radical cation decolorization assay, Free Radic. Biol. Med. 26 (1999) 1231-1237.

[27] M. Kapiszewska, E. Sołtys, F. Visioli, A. Cierniak, G. Zajac, The protective ability of the Mediterranean plant extracts against the oxidative DNA damage. The role of the radical oxygen species and the polyphenol content, J. Physiol. Pharmacol. 56 (2005) 183-197.

[28] Y. Wang, S. Wang, W. Cui, J. He, Z. Wang, X. Yang, Olive leaf extract inhibits lead poisoning-induced brain injury, Neural Regen. Res. 8 (2013) 2021-2029, https:// doi.org/10.3969/j.issn.1673-5374.2013.22.001.

[29] A. Cumaoglu, L. Rackova, M. Stefek, M. Kartal, P. Maechler, C. Karasu, Effects of olive leaf polyphenols against $\mathrm{H} 2 \mathrm{O} 2$ toxicity in insulin secreting bcells, Acta Biochim. Pol. 58 (2011) 45-50.

[30] S. Rigacci, M. Stefani, Nutraceutical properties of olive oil polyphenols. An itinerary from cultured cells through animal models to humans, Int. J. Mol. Sci. 17 (2016) 843, https://doi.org/10.3390/ijms17060843. 